\title{
Critics on Feminist Influence for the New Bhikkhunī Revival Debate in Sri Lanka: Ethnographical Inquiry
}

\section{Gihani De Silva}

Department of Social Sciences, Faculty of Social Sciences and Languages, Sabaragamuwa University of Sri Lanka. gihani.desilva@yahoo.com

\begin{abstract}
Feminist academia and activists are the pioneers of revival of bhikkhunī order in Sri Lanka. These International and local proponents are being criticized for their very attempt. Thus, the main objective of this study is to recognize dasasilmātās' responses towards this intermediation of feminist activism, as dasasilmātās are the oldest alternative form of female renunciant group, who highly affected by the new status of bhikkhunī-hood. This ethnographical study has conducted using observation and interview methods, employing ten executive members of Silmata Jathika Mandalaya (SMJMEC), five dasasilmātās in western province, four bhikkhunīs and one government officer under purposive sampling method. According to ethnographical findings, most of dasasilmātās do not accept International bhikkhunī higher ordination ceremonies and contribution made to them by local and international feminist (female) activists. But, they do not mention about bhikkhu activists as feminist activists. However while criticizing, they highlight the Western feminist influence. Therefore, they hardly identify the high profile of Asian feminist involvement in revival of bhikkhuni order in Sri Lanka. For instances, in reality there were multiple transnational bhikkhuni advocacy projects. Dasasilmātās not only equates feminism with the West, but also with elite class status. Further, inner disagreements or fractions among local feminists and activists in the early period of the bhikkhuni revival movement are important concerns.
\end{abstract}

Keywords: Feminist, Revival, Higher Ordination, Transnational, elite

\section{Introduction}

The bhikkhuni order which declined from around the $11^{\text {th }}$ century in Sri Lanka, has emphasized the necessity of four fold Buddhist community, including bhikkhu, bhikkhunī, upāsaka and upāsikā in Theravāda tradition. The disappearance of bhikkhuni-hood caused difficulties for Buddhist women to renunciate their lay life within the institutionalized religious sphere as it is solely controlled by the patriarchal hierarchies. According to feminist scholars, institutional patriarchal religious hierarchies needed to keep religious women 
under a subjugated and submissive framework, where women were restricted for achieving their spiritual liberation in institutionalized manner. Therewith, the conservatives or opponents considered the very attempt of reestablishment

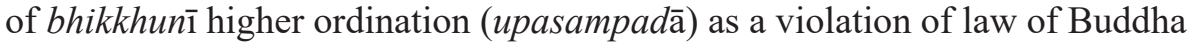
or defilement of pure Buddhism. Nevertheless, the new bhikkhunī movement, empowered by its transnational Buddhist feminist networks could not be easily brought to an end by those supreme authorities (Tomalin 2013: 108). These Buddhist feminist movements, which were sponsored by feminist scholarship and community is regarded as an inevitable or unstoppable movement that spread into areas even where there was no bhikkhuni order previously (De Silva 2009: 25).

Thus, the underlying principles of the attempt of resurgence of bhikkhuni higher ordination again become problematic when it comes to view that is more critical. The attempt of resurgence of bhikkhuni-hood is not just mere action, but has underlying principles of acquiring liberal notion of equality and freedom. This has made the bhikkhuni-hood, a transnational or a global project for constructing the ideal of the higher ordained bhikkhunī. Creating such a discursive space for female renunciants is in fact a product of the transnational project. "The ideal of higher ordained nun... represents a homogeneous ideal that evokes the egalitarian vision of a sisterhood among Buddhist nuns across the globe" (Salgado 2013: 211-213). Chandra T. Mohanty comments on the characterization of women's condition as globally homogeneous. She recognizes them as an assumption of "women as a unified group on the basis of secondary Sociological universals. What binds women together is an ahistorical notion of the sameness of their oppression and, consequently, the sameness of their struggles" (1991, 51-80). If we understand the global project of bhikkhuni revival in terms of Mohanty's argument, the dominant global ideal of bhikkhuni-hood has evaded the differences among and within female renunciants. In that sense, it has forced to accept the bhikkhunīi deal. In turn, it not only becomes a problem of reclaiming the women's religious rights, but an increasing tension and controversy between the local and the transnational conceptions of female renunciation. As Borchert (2007) argues, "contemporary Buddhism is marked by a tension between the transnational and the national" (2007, 529).

Therefore, imposing an external influence on different cultural setting is not a simple phenomenon; in fact, there will be counter responses to above local and transnational forces. Thus, it is important to look into the lived lives of the female renunciants who might be ignores such influences or what these alternative groups of non-bhikkhunis think about the higher ordination opportunities that are offered to them. Specifically, dasasilmātās as an alternative form of female renunciants do not accept what they are granted. Instead, resistances, striking against could be visible. Therefore, this essay 
will focus on dasasilmātās responses to the feminist involvement, as they are pioneers who brought the bhikkhuni order to Sri Lanka. Although, responses of dasasilmātās to the new bhikkhunī order carried a huge debate, here I will bring only the critics on feminist influence (female) and internal disagreements within the proponents of the bhikkkhuni movement.

\section{Research Methodology}

This ethnographic study was carried out for the very purpose of documenting the lived lives of Sri Lankan Buddhist female renunciants. As a qualitative study, ethnography is the most appropriate research tool for this study, as it involves documenting believes of female renunciants and practices from their own perspective. According to Fetterman (2010) "ethnography is about telling a credible, rigorous, and authentic story. Ethnography gives voice to people in their own local context, typically relying on verbatim quotations and a 'thick' description of events" (2010: 1). This thick description of human experiences comes under the phenomenological methodological tradition, which allows for an interpretive understanding of the social world. Thus, it was expected to interpret the renunciants responses in order to gain the constant meaning from the dialog with them.

Observation is a main tool in an ethnographer's toolbox. Mostly, ethnographers use different forms of participant observation. "Participant and nonparticipant observation are at two ends of a continuum, and most ethnographers engage in a mix of participant and nonparticipant observation, depending upon the context and circumstances" (Fettterman 2010: 21). Therefore, the observation method that I have used in the present study is mixed of participant and non-participant observation method. In-depth interview was also part of this ethnographic fieldwork. Thus, these two methods were important as they could use in documenting views of female renunciants in broader way. All the respondents were given assumed names (allonym) in the study.

\section{Brief History of New Bhikkhunī Revival Movement in Sri Lanka}

Revival of bhikkhunī Order has been regarded as one of the most controversial issues within the mainstream Buddhism recently. Due to the overwhelming attention that has been paid to the above issue academically and socially it has turned into complex level. However, the recent history of bhikkhunī is unfolding. It is sometimes assumed that, the efforts in restoring the bhikkhuni order arise only under the influence of the Western Buddhist feminist movement around 1980s (Barnes 1994: 144; Boucher 1988: 91-92). Nevertheless, arguments regarding reestablishment of the bhikkhunī order in Sri Lanka came into sight much earlier. Anagarika Dharmapala advocated restoration of the order in 1890s. He encouraged activities of female renunciants and wrote that, they 
were necessary for the welfare of Buddhism (Bartholomeusz, 1944: 44-48). From the 1930s, the topic was debated in the newspapers and among bhikkus and scholars in Sri Lanka.

Sakyadhitha (daughters of the Buddha), an international Buddhist women's association, who work for achieve Buddhist women's rights, has been played a significant role in this regard. One of the stated objectives of Sakyadhita: International Association of Buddhist Women was "to assist women who wish to obtain ordination and work toward establishing full ordination for Buddhist women in countries where it is not currently available," where it does not currently exist (Mrozik 2009: 360). When it comes to the reestablishment of the bhikkhuni order in Sri Lanka noticeable efforts were seen in late 1990's. But, in 1988, the first group of five Sri Lankan dasasilmātās (including Ayya Khema) travelled to Los Angeles to receive higher ordination at Hsi Lai Monastery from Taiwanese bhikkhus and bhikkhunis (Foguangshan) (http:// www.bhikkhuni.net/wp-content/uploads/2013/08/International-BhikkhuniDay-2011.pdf). Upon their return to Sri Lanka, however, they did not receive public recognition as bhikkhunis. As a result, they have continued to live as dasasilmātās as they did before.

In 1996 ten Sri Lankan dasasilmātās travelled to Sarnath, India to participate in the dual higher ordination led by the Sri Lankan Ven. Mapalagama Wipulasara together with the Sri Lankan bhikkhu sangha and the Korean bhikkhuni sangha, led by the President of the Council of Korean bhikkhuniss, Kwang Woo Sunim. The first President of Sakyadhita in Sri Lanka, Kusuma Devendra, decided to become a renunciant and was fully ordained as one of the first bhikkhunīs. In 1998, twenty Sri Lankan dasasilmātās received bhikkhunī precepts at an International Higher Ordination arranged by Master Hsing Yun and Foguanshan at Bodhgaya in India together with 132 women from 22 countries (De Silva 2004: 128-129).

It would be a mistake to think that Sakyaditha is the only organization that sponsors the bhikkhun̄ ordination in Sri Lanka. International ordination ceremonies were criticized as they were influenced by the Mahāyāna Tradition. A group of people who were having these kinds of intentions laid by Ven. Inamaluwe Sumangala, the abbot of the Golden temple in Dambulla, engaged in promoting the reestablishment movement. The Sri Lanka 'Bhikkhunī Reawaking Organization' (bhikkhun̄̄ Sāsana abhiviruddhi Samvidhanaya) with, Ven. Inamaluwe Sumangala Thera as its president, sent about four hundred letters to dasasilmātā in Sri Lanka describing plans for a bhikkhun̄̄ ordination, and invitations to apply for it (De Silva 2009: 31). Out of the two hundred applicants, a committee including four nuns, one monk, and a lay follower selected eighty dasasilmātā. "On 12 July, 1997, twenty-six of the selected women were ordained as novices by Ven. Inamaluwe Sumangala. They were 
educated for nine months in a remote meditation center in Kalundewa near Dambulla" (De Silva 2009: 31). Nevertheless, this project was given up when there was an invitation from the Foguangshan in Taiwan arrived to participate in the International full Ordination program in Bodhgaya.

However, in 1998, further Sri Lankan dasasilmātās received the dual higher ordination in their own country from Sri Lankan bhikkhus and bhikkhunīs. On March 14, soon after the bhikkhunīs returned from Bodhgaya, Ven. Inamaluwe Sumangala organized and administered ordination to 22 dasasilmātās that had completed their training at his center. With the assistance of the bhikkhunis that had been ordained in Bodhgaya, five senior monks conducted a bhikkhunis ordination at the Rangiri Dambulla Monastery in the same hall where monks ordinarily receive their ordination (De Silva 2004: 129). This bhikkhuni ordination was the first to be held on Sri Lankan over 1000 years. Further groups of dasasilmātās are currently being trained to receive the higher ordination in Sri Lanka. Beside Dambulla there are three other training centers are at Newgala (Kegalle), Millaniya (Horana-Kalutara) and Eheliyagoda. Although, these bhikkhunis now perform certain religious and ecclesiastical activities on an equal footing with the monks, and thus enjoy better religious and social status - nevertheless they are still waiting to be officially recognized as part of the Buddhist sangha in Sri Lanka.

\section{Criticism for Feminist Influence}

"Feminist influence" is a buzzword used in related to the bhikkhuni revival debate equivocally. Therefore, as Mrozik (2009) has pointed out, concepts such as gender equality, rights, and feminism are frequently characterized by both supporters of and opponents of bhikkhunī ordination as Western secular concern alien to Asian Buddhist religious communities (See more in Mrozik 2009). Therefore, it should be very careful while raising the arguments about the feminist influence over the bhikkhuni debate, whether the perceived arguments are going to be depicted in famous stereotypes as feminism is 'Western' or the reality of multiple transnational bhikkhuni advocacy projects.

Newly established bhikkhunī revival movement was highly criticized by dasasilmātās as a whole. Some dasasilmātās even rejected the presence of bhikkhunis in Sri Lanka. According to them, even addressing them as bhikkhuni is similar to giving sanction over them. The first International bhikkhunī higher ordination ceremony (in 1996) was heavily criticized when compared to the other ordination ceremonies. Every aspect of it such as the background, sponsors, organizers, the international participants and the ordination proceedings were subjected to criticism by the dasasilmātās. 
However, I would like to start the discussion of feminist influence with the views of Deputy Commissioner of the Department of Buddhist Affaires as his views reflects the government, mahānāyaka sangha and the SMJM. As one could expect, he critizied the involvement of feminism in the matters of bhikkhunī. He identified the intermediation of feminists as:

It is just like waves, which derive time to time and decline in the world. There are so many movements likewise. If there is no donation, gradually they will end up. Therefore, there is no need to worry about them (Field data, 2011-12).

Although, he tried to blurb the movement as a temporary awakening, this is clearly refused by the scholars, bhikkhus, bhikkhunis and lay supporters who think the movement as an unstoppable one (De Silva 2009; Mrozik 2009). Even this was echoed by the bhikkhunī respondents. For instance, Subodha bhikkhunī who was a former dasasilmātā said that, "we never turn back, as we are the daughters of Buddha. It is our right to become bhikkhunis (Field data, 2011-12)." Seemingly, Subodha bhikkhunī who is inspired by feminist ideas is not going to recede on any matter. However, deputy commissioner protested against considering the religious rights as women's rights. According to him, feminists have misinterpreted the bhikkhunī ordination as a women's right. He interrogated about how anyone can change the traditional religious matters for any reason. Accordingly, there is an accepted method to do it. Thus, it would be a violation of established rules. Therefore, "if someone considers bhikkhunī ordination as a women's right, it is a problem of his or her aim (Field data, 2011-12)." When this was asked from the bhikkhun̄ respondents, Vajira bhikkhuni pointed out that, "there is no legal recognition for bhikkhuni-hood that is why we have to struggle over the bhikkhuni ordination. If it is fully sanctioned no one need to worry (Field data, 2011-12)." The statement echoes that, bhikkhunī higher ordination has become an acquiring of women right due to the lack of recognition. The necessity of higher ordination has arose within a context of deprivation as there had been many prior attempts to resurgence of bhikkhuni order in some of the Theravāda traditions, but those attempts were relinquished. These abandoned attempts have been given a new face, strengthened up and empowered by putting forward feminist ideals such as gender equity, rights etc. Therefore, bhikkhunīs are emphasizing that, feminist influence over the bhikkhuni matter is not something spontaneous, rather pervasive due to the lack of concerns over the issues of Buddhist renunciants in general and bhikkhunīs in particular by the pertinent authorities. Vajira bhikkhunī added that,

This is not something about women's right, but we asked for our monastic rights. We are not just laywomen, but a part of the monastic community. Why can't we have our monastic rights? (Field data, 201112) 
On the one hand, this demonstrates that once a woman gets ordained, she no longer considers femininity (Salgado 2013: 6-7). Likewise, when a man renunciate his lay life, no longer his masculinity or men's rights going to be considered. Because his rights are going to be identified under the monastic rights. But, for female renunciants it does not work so. Their rights for monasticism always recognized as women's right or in laywomen's position. This lack of recognition is a result of the ambiguous position of Buddhist female renunciation in the society. Therefore, people who work for female monastic rights often are being labeled and stigmatized under the group of women's right. On the other hand, Vajira bhikkhuni might reluctant to mention bhikkhunī-hood as a women's right, after having knowledge and experience on possible oppositions can be aroused. Therefore, she might tactfully avoid in saying so. However, the way the Vajira bhikkhuni claimed for her monastic rights undoubtedly challenges the conservative view. In the light of these views, although it seems that the Deputy Commissioner is concerned about the protection of the sāsanaya, his voice reflects the patriarchal values which expect to keep Buddhist female renunciants under the control of institutionalized monasticism. However, bhikkhuniss seem to be well aware of these counter views.

Further, dasasilmātās especially the SMJM executive committee members demonstrate the same point of view as the government officer. Padma dasasilmātā (SMJMEC) added her views in this regard,

Sāsanaya is like an ocean. Rubbish comes to ocean from everywhere. But it does not remain and cleanse itself. Do not worry about those rubbish waves. They will cleanse up. The people who plug the sand soon will understand the reality... (Field data, 2011-12)

Although Padma dasasilmātā did not mention about the feminists directly, indirectly she included all the international and local activists who try to meet with their demands over the bhikkhuni-hood. She gibes the attempts and resembles it to a purposeless one. By doing so, she devalued the whole attempt, which she thinks that never will be a part of sāsanaya even in the future. On the one hand, this statement expresses the tension that she is to encounter as an alternative group of Buddhist renunciants. On the other hand, criticisms and condemnations are used as a means of labeling the bhikkhun $\overline{1}$ movement and its activists. By doing so, she just ignores the pressure upon them, which has become almost out of their control.

The above statement reveals the tension and the counter response that dasasilmātās bring forth against the bhikkhunī revival debate. Gothami dasasilmātā stated the underlying reasons, why dasasilmātās have to respond 
in such a manner. She questions the intentions of the people who worked for revival of bhikkhuni order both locally and internationally.

We should be shame of ourselves for not being able to come to an agreement on bhikkhunī matter. There is nothing but our timidity. Bhikkhus allow them to do this and that. Then they scold others for no reason. These Westerners give us what they desire, in the manner they expect. They are absorbing the spirit from us, but bestow it back as their own belonging (Field data, 2011-12).

This graduate dasasilmātā who has experience both as a bhikkhunī and dasasilmātā perceive the issue in the light of alienation. Accordingly, as she has explained furthermore, Buddhism has spread into the 'Western world' from its 'native lands.' Now it is being reintroduced in new forms. Thus, feminist involvement is regarded as such a form, although she did not name it directly here. Undoubtedly, these new phenomena are bringing changes with many positive and negative impacts from time to time. The problem is the way it is carried-out or the underlying meaning. In her work, Cheng stressed about this.

... The implication hidden behind such arguments are that goes like this: not only should Asian Buddhists appreciate and even celebrate the changes brought by Western feminists, but also if Asian Buddhists do not change according to the suggestions made by Western feminists, Asian Buddhism will forever be patriarchal, unable to change and unworthy of practicing (http://dharmafolk.org/2008/11/24/westernbuddhist-feminist-oppressors/).

Thus, there would be no change in these Asian lands unless Westerners bring in new transformations. For instance, Sandy Boucher has suggested that Western women transform Buddhism and make Buddhism a better and more humanitarian religion (1988: 148- 206). On the one hand, such claims marginalize the Asian people and their effort in changing the prevailing practices. Thus, the Westerners expect a mentality of dependence to maintain their superiority. As Cheng suggests Western women did not come along to transform Buddhism it is Buddhism that is always transforming (http:// dharmafolk.org/2008/11/24/western-buddhist-feminist-oppressors/). Therefore, not all these Sri Lankan female renunciants are seeking salvation through the Western feminist involvement but they are rather willing to improve their own monastic status. However, the question is about the correct leadership and guidance. Here Gothami dasasilmāta not only blames the international parties, including feminist, but the pertinent authorities who are silent over the issue. The bhikkhuni issue was escalated to such a level due to the negligence of the pertinent authorities. But, here I would like to raise one more issue as I have mentioned in the very begging of argument under 
the feminist influence, Gothami dasasilmāta has resemble all the attempts of reintroduction of bhikkhuni-hood under the broader category of 'Western Buddhism.' This explanation has an impact on efface or neglect the influence of the East Asian countries made over bhikkhunī debate.

Here, I would like to move the discussion further into dasasilmātās responses towards mediation of the local female feminist activists. Several influential female figures who have undertaken the task of bringing bhikkhuni order to Sri Lanka can be identified in this regard. They are bhikkhunī Kusuma, Ranjani De Silva and Hema Goonathilaka. Apart from bhikkhunī Kusuma, most of the dasasilmātās and even some of the executive committee members of SMJM are not well known other activists. However, some of the dasasilmātās have got to know about them, as they conduct some research on these dasasilmātās. For instance, one of the pioneering activists (not mention the name) has contacted Dhammadhira dasasilmātā (SMJMEC) over the phone once and she has thought that activists was from one of the women's organizations. In her words,

Those women organizations are not doing anything. She (not mention the name) phoned me once. Even she did not come to meet me. I told her that, although I did not have a degree, I have acquired knowledge through life experiences. They say that, they talk on behalf of us, but nothing happens. Can you see any improvement in the status of dasasilmātā? They just take information, but nothing going to be done. Everyone come and asks about our difficulties, but nothing changed. Those 'loku nōnala' (elite women) get together and just talk nonsense. They do not understand anything, because they just think of us staying inside the cold rooms (Field data, 2011-12).

Although this is not solely about that activist, she was part of the story. This dasasilmātās, who has faced numerous troubles with an unregistered dasasilmātā education center, seems to express her protest against those who have taken information from them but have done nothing in return. When Dhammadhira dasasilmātā was contacted for present research, she refused at once, saying she does not want to talk with one who represents a women's organization. She was frustrated on such organizations. Her concern is that although there is numerous government and non-government organizations working on women's rights the burning issues of Buddhist renunciants have not been addressed by any party. When she was asked about the feminist involvement in the bhikkhuni issue, she replied saying that,

They have created all these endless troubles. I know about some of my bhikkhuni friends who are worried about recognition of government and mahānāyaka sangha. I myself do not like to live in such a pressure. 
That is why I am not going to become a bhikkhuni. Otherwise, I join the Order (Field data, 2011-12).

She seems to put all the blame on feminist activists. The reason behind such a response is the incapability of these feminist activists and other progressives to provide possible solutions to the present problems (Unsanctioned bhikkhunihood, identity card problem and lack of education facilities). According to her, although the bhikkhuni revival movement is initiated with the strong backing of feminist activists, when it comes to legal sanction bhikkhunis have to bargain it with their own effort. Even the feminist activists were not in a position to change it. That is why Dhammadhira dasasilmātā mentioned this as an endless trouble. In other words, she hinted that, although there are many groups to support newly ordained bhikkhuni in the outset, when it comes to above said troubles, bhikkhunis who have selected it as their new renunciation path have to face the problems alone. As Cook (2010) pointed out, some mae chees respond to local feminist activists in Thailand in a similar manner. For instance, one mae chee said that, "Chatsumarn is a women's rights campaigner. If lay people didn't pay attention to her, she would disrobe and find another way to campaign" (2010, 164). Although Cook has identified, "both the monasticization of mae chee and the bhikkhuni movement must be understood as part of a broader context in which women are increasingly being recognized in positions of privilege and respect" possible objections was alarmed against the feminist involvement in the debate by local alternative female renunciants (Cook 2010: 164).

However, if we turn back to the above discussion again, this not indicate that, feminist activists of the bhikkhun̄ issue did not do anything for claiming the legal sanction for the bhikkhuni issue, but they were not succeed in it, in before inflexible sangha authority. For instance, Hema Goonathilaka was the only female member of the Presidential Steering Committee of the $2600^{\text {th }}$ Anniversary Commemoration of the Buddha's Enlightenment. According to her, she was not in a position to speak on behalf of Buddhist renunciants in that committee, although she was willing to do something in the presence of the President (Academic workshop on the Sri Lankan Bhikkhunī Revival, 2012). She may have gained that position in the committee due to her contribution as a Buddhist scholar and activist. However, there was no any representation from the Buddhist female renunciants. Instead, they have appointed a laywoman (although she is a scholar), where it was to constitute a parliamentary bill on dasasilmātās. However, even Hema Goonathilake was speechless on the matters of bhikkhuni-hood in the committee. Although, parliamentary bill was formed instantaneously, still the Department of Buddhist affaires is revising it. Though it seems that dasasilmātās are silent over the omission of the bill, they censured their resistance over it. Dhammadhira dasasilmātā expresses 
the passivity of her position in the SMJM, and how she has become a 'yeswomen.'

We heard about that parliament bill at the annual meeting of the SMJM. But, nothing was discussed further. They make them and implement them. Other than that, we can do nothing. We even are looking for this said bill... (Field data, 2011-12)

Dhammadhira dasasilmātā above explanation is a good example of the reflection of inner disagreements in SMJM and their relationship with government and sangha authorities. Although she had to be a yes-women in SMJM meetings, there are hidden counter responses.

However, here I would like to move back to the Dhammadhira dasasilmātā statements as it provided a prime example of how the dasasilmātās perceive these local feminist activists vice a versa to their expectations. I would argue that dasasilmātās not only equate feminism with the 'West,' but also with the elite class status. If we move to the initial stage of local feminist involvement in very brief, especially local feminist activists believe that, they made all the change come true regarding ambiguous status of female renunciants in Sri Lanka. As Ranjani De Silva once stated, "nuns in Sri Lanka were helpless and called as 'pottani genu' (women who carry their belongings baggage)... by seeing the nuns in all over the world participated for the conference, I wanted to change it" (https://www.youtube.com/watch?v=d_yeu6RrJ2g). Although she intended to change the ambiguous status of the Sri Lankan renunciants, her statement reflects the mindset over the dasasilmātās by a different higher social strata. Moreover, it reflects the general social image of dasasilmātās at that time. But, there were some prominent dasasilmātās and dasasilmātās $\bar{a} r \bar{a} m a$ at that time.

However, Ranjani De Silva joined with Ayya Khema and went to the Sakyadhita International conference on Buddhist nuns, Boddhgaya, in India in 1987. As she mentioned, by seeing the higher status of renunciants all over the world, she wanted to change the dasasilmātās submissive position. Hereafter, with a group of elite women she meddled with organizing huge projects such as organizing the Sakyadhita conference in Sri Lanka in 1993 (https://www. youtube.com/watch? $\mathrm{v}=\mathrm{d} \_$yeu6RrJ2g). Meanwhile, though they did smallscale projects and programs to female renunciants, but it did not take the attention. Rather continuously implementing other types of projects which can be useful to dasasilmātās (promoting education, providing material stuff, practical knowledge of social services likewise counseling), they moved to bhikkhuni project. According to what I have observed, they did not create an appropriate prior background, which was a necessity to re-establishment to the bhikkhuni ordination. Although they made considerable changes in status of 
dasasilmātās, it was not trickled down as their effort. For instance, bhikkhunī Kusuma was able to meet all the high ranked politicians and officers, including former President Jayawardena, Elina Jayawardena, Minister of Buddhist Affaires Mr. Hurulle, Commissioner of Buddhist affaire Eardly Ratwatte and made some new room to dasasilmātās as she stated (https://www.youtube. com/watch? $\mathrm{v}=\mathrm{d} \_\mathrm{yu} 6 \mathrm{RrJ} 2 \mathrm{~g}$ ). But, even this effort was not identified as her, but the government and sangha authority. In other words, she is not admired for these attempts by most of the dasasilmātās.

When they came to the decision of changing the submissive status empowered through bhikkhunī ideal, but they seems did not consider dasasilmātās' views. Although these, pioneering activists has been already conducted surveys on dasasilmātās, vinaya reflections etc. they paid less attention to the most affected group that would be influenced by. They did not answer well enough to the possible questions such as, are they willing to accept (bhikkhuni-hood), are they ready to accept it, what the possible reactions would be? That is why new bhikkhunī movement becomes problematic in terms of social movement. In this sense, it is a movement that reflected the expectations of a particular elite stratum at that time. Although they tried to tackle down with bhikkhuni issue as a vinaya problem, it was not worked well. Vinaya argument was not well accepted as a solution.

Moreover, disparities between these feminist activists and dasasilmātās were still visible. For instance, while these activists work for the female renunciants, they use to differentiate themselves from the rest of the dasasilmātās. They keep gap which impact on creating disparities between the dasasilmātās and

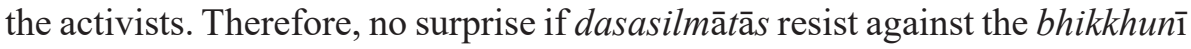
activists who comes from different higher social strata. It is not only local feminist activists and dasasilmātās views were contradictory with each other, but I could find some inner disagreements over certain issues among the activists. It has badly harmed to the work that they has done on the revival of bhikkhuni-hood. Moreover, this has led to create inner fractions within the newly established bhikkhuni movement as the activists are working on their own agendas.

\section{Conclusion}

The new bhikkhuni revival has brought considerable attention to the contemporary female renunciants than ever before, due to the globalized social waves, such as the feminist movement since 1970s. With the influence of feminism, female renunciants in Theravāda tradition were able to create an institutionalized higher ordained space for themselves, which was prohibited or tabooed. Yet, conservative Theravāda tradition in many countries is not sensitive to the issue and reluctant to give legal sanction. Bhikkhuni revival 
movement gained its impetus from some of the Sri Lankan leading bhikkus and few women from the elite class background who were inspired by International Buddhist Women's Organizations. In this sense, there is an issue in considering the bhikkhuni resurgence as a social movement. The new bhikkhuni movement was severely criticized by dasasilmāt $\overline{\boldsymbol{a}}$ s. Thus, one of the noticeable facts so far is the denunciation of the feminist influence on the bhikkhuni issue. The views demonstrated the assumption that advocates for bhikkhuni ordination are giving into the pressures of "Western" feminists. But, in reality there were multiple transnational bhikkhunī advocacy projects. Dasasilmātās not only equates feminism with the West, but also with elite class status. Therefore, they refuse to accept that local feminist activists have brought considerable changes to the present ambiguous status of female renunciation. Moreover, inner disagreements or fractions in the early period of the bhikkhuni revival movement could be visible. Finally, Dasasilmāt $\overline{\boldsymbol{a}}$ do not accept whatever they have been granted, instead counter responses are visible. This indicates the present complex nature of contemporary Sri Lankan Buddhism.

\section{References}

Barnes, Nancy J. 1994. 'Women in Buddhism.' In Today's Women in World Religions. Edited by Arvind Sharma, 105-133. Albany, NY: State University of New York Press.

"Bhikkhuni Resurrection-The Revival of Bhikkhunī Ordination in Sri Lanka." The Buddhist Society of Victoria, Accessed March 12, 2014, https:// www.youtube.com/watch?v=d_yeu6RrJ2g.

Borchert, T, 2007. "Buddhism, Politics, and Nationalism in the Twentieth and Twenty-first Centuries," Religion Compass, vol. 1, no. 5, 529-46.

Boucher, Sandy. 1988. Turning the Wheel: American women creating the new Buddhism. Boston: Beacon Press.

Bartholomeusz, Tessa. 1944. Women under the Bo Tree. New York: Cambridge university press.

Cheng, Wei-yi. "Western Buddhist Feminist Oppressors." Accessed May 16, 2014. http://dharmafolk.org/2008/11/24/western-buddhist-feministoppressors/.

Cook, Joanna. 2010. Meditation in modern Buddhism: Renunciation and change in Thai monastic life. Cambridge University Press.

De Silva, Premakumara. 2009. "Discourses and counter discourse(s) on the new bhikkhuni order in Sri Lanka: An ethnographical inquiry." Nivedani, 25-41. 
De Silva, Ranjani. 2004. "Reclaiming the Robe: Restoration of the Bhikkhuni Order in Sri Lanka." In Buddhist Women and Social Justice: Ideals, Challenges, and Achievements. Edited by Karma Lekshe Tsomo, 119135. Albany, NY: State University of New York Press.

Fetterman, David M. 2010. Ethnography: Step-by-Step. California: Sage Publications.

Mohanty, Chandndra T. 1991. "Under Western Eyes: Feminist Scholarship and Colonial Discourses," In Third world and the politics of Feminism, Edited by Chandra T. Mohanty, Ann Russo and Lourdes Torres, 51-80. Bloomington and Indianapolis: Indiana University Press.

Mrozik, Sussane. 2009. "A Robed Revolution: The Contemporary Buddhist Nun’s (Bhikṣuṇī) Movement.” Religion Compass 3, no. 3, 306-378.

Salgado, Nirmala S. 2013. Buddhist Nuns and Gendered Practices: In search of Female Renunciants. New York: Oxford University Press.

Sudhamma. Bhikkhuni. "A Personal Perspective on Vinaya, the Rules for Bhikkhus and Bhikkhunis." Accessed August 25, 2014. http://www. bhikkhuni.net/a-personal-perspective-on-vinaya-the-rules-for-bhikkhusand-bhikkhunis/.

Tomalin, Emma. 2013. "Gender Buddhism and Bhikkhuni Ordination: Transnational strategies for the Feminist transformation of Religion in the $21^{\text {st }}$ Century." In Religion, Gender, and the Public Sphere. Edited by Niamh Reilly and Stacey Scriver, 108-120. New York: Routledge.

Academic workshop on the Sri Lankan Bhikkhunī Revival. The American Institute for Lankan Studies, Colombo, April 28 -29, 2012. 